\title{
Biodiversity: So much more than legs and leaves
}

AUTHORS:

Don A. Cowan ${ }^{1}$

Edward P. Rybicki

Marla I. Tuffin ${ }^{3}$

Angel Valverde ${ }^{1}$

Michael J. Wingfield ${ }^{4}$

\section{AFFILIATIONS:}

${ }^{1}$ Centre for Microbial Ecology and Genomics, Department of Genetics, University of Pretoria, Pretoria, South Africa

${ }^{2}$ Department of Molecular and Cell Biology and Institute of Infectious Disease and Molecular Medicine, University of Cape Town, Cape Town, South Africa Institute for Microbial Biotechnology and Metagenomics, University of the Western Cape, Cape Town, South Africa

${ }^{4}$ Forestry and Agricultural Biotechnology Institute, Faculty of Natural and Agricultural Sciences, University of Pretoria, Pretoria, South Africa

\section{CORRESPONDENCE TO:} Don Cowan

EMAIL:

don.cowan@up.ac.za

\section{POSTAL ADDRESS:}

Centre for Microbial Ecology and Genomics, NW2 Building, University of Pretoria, Pretoria 0028, South Africa

\section{KEYWORDS:}

bacteria; endemism; fungi; genetic resources; viruses

\section{HOW TO CITE:}

Cowan DA, Rybicki EP, Tuffin MI, Valverde A, Wingfield MJ. Biodiversity: So much more than legs and leaves. S Afr J Sci. 2013;109(11/12), Art. \#a0037, 9 pages. http://dx.doi. org/10.1590/sajs.2013/a0037

(C) 2013. The Authors. Published under a Creative Commons Attribution Licence.
Microorganisms inhabit virtually every possible niche on Earth, including those at the outer envelope of survival. However, the focus of most conservation authorities and ecologists is the 'legs and leaves' side of biology the 'macrobiology' that can be seen with the naked eye. There is little apparent concern for the preservation of microbial diversity, or of unique microbial habitats. Here we show examples of the astounding microbial diversity supported by South Africa's ecosystems and argue that because microbes constitute the vast majority of our planet's species they should be considered seriously in the future protection of our genetic resources.

\section{Introduction: The microbial world}

Despite suggestions from popular science programmes, planet Earth is not owned by insects (or humans): it is a microbial world. (For the purposes of this article, we classify 'microbial' as including the bacteria and archaea (prokarya), fungi and yeasts (eukarya) and viruses.) Microorganisms inhabit virtually every possible niche on Earth, including those at the outer envelope of survival. ${ }^{1}$ Deep sea hydrothermal vent waters at $120{ }^{\circ} \mathrm{C}$, the ancient sub-glacial lakes of the permanently frozen Antarctic continent, fractures in geological strata kilometres below our feet, sediments far below the ocean floors and even the clouds far above us are habitats for microbial life. In fact, the only sterile environments on Earth are those where conditions exceed the stability limits of molecular structures, such as in molten volcanic lava.

The total number of microbes on the planet is certainly not known with any accuracy, but estimates suggest $>1 \times 10^{31}$ microbial cells. ${ }^{2}$ Various commonly quoted statistics give some sense of the vastness of the microbial biosphere: there are more microbial cells in a single human body than human cells ${ }^{3}$; the deep subterranean biosphere contains more microbial biomass than the entire photosphere ${ }^{4}$; and if all the $2 \times 10^{31}$ virus particles on the planet were laid end to end, they would extend from Earth, past the Andromeda galaxy, to the next galactic supercluster over 100 million light years away (own calculation). Indeed, viral genes probably represent the largest single grouping of genetic material on this planet. ${ }^{5}$

Cellular microbial 'species' diversity is also staggeringly high. Current estimates for fungi and bacteria are around $1 \times 10^{6}$ and $1 \times 10^{7}$, respectively, ${ }^{6,7}$ but these are made more insecure by the definition of what a microbial species actually is. (The 'species' concept is not particularly well designed for the microbial world, where lateral gene transfer allows the regular interchange of genetic material across taxonomic boundaries. However, in the absence of a better system of classification, it is still used ubiquitously.) Nevertheless, the cellular microbial pan-genome, representing the total genetic complement of all these 'species', constitutes the next largest genetic resource on the planet after viruses. Indeed, the bacteria living in us ${ }^{8}$ contribute far more genes -100 -fold more - to our metagenome than we do!

Accessing this resource is another matter. Their tiny size and lack of obviousness is only one barrier to discovery: with the development of modern molecular phylogenetic methods in the 1970s came the realisation that most of the world's microbial, and therefore total genetic resource, had yet to be accessed. ${ }^{9}$ This inaccessibility is now widely known as the problem of the 'unculturables' as far as cellular organisms are concerned, ${ }^{10}$ probably more accurately termed the 'uncultured', with reference to the fact that the culturing of these species is not impossible but science has yet to devise and apply the appropriate methods. For viruses, which are absolutely dependent on a cellular host for their life cycle, the problem is compounded by our very limited knowledge of what the hosts are for the viruses we find in soil, seawater and even in the human body.

Thus, our general understanding of biodiversity is due a major overhaul. Particularly because, until recently, conservation authorities were largely concerned with the 'legs and leaves' side of biology, or the 'macrobiology' that can be seen with the naked eye. ${ }^{11}$ Unlike their larger and more charismatic cousins, no one was particularly concerned with preserving microbial diversity or unique microbial habitats - yet these organisms constitute the largest part of our biosphere, both in terms of mass and in diversity, and we know next to nothing of how they may be linked in interactive and co-dependent webs. A case in point here is the Karoo fracking proposal: companies intend to inject vast quantities of water and other substances deep underground in order to fracture ancient rocks and release gas - a substance that has almost certainly been created, over millions of years, by biological processes by organisms that we are largely ignorant of. What damage might we be doing to an environment that is largely unknown to us, yet seems ripe for exploitation? What processes might we be disturbing that could take millions of years to re-establish?

To illustrate just how long biological processes can be when microbes are involved, consider the fact that bacteria which are found $30 \mathrm{~m}$ below the Pacific Ocean floor in sediments, ${ }^{12}$ laid down over 86 million years ago, are living so slowly that individual cells may qualify as the oldest organisms on this planet. We have only just discovered them; we have no idea what else is there or how it lives.

The fact that the small size of microbes potentially makes long-distance dispersal by water ${ }^{13}$ and wind ${ }^{14}$ a major mechanism, and given their fast growth rates and their enormous population sizes, it has been assumed that microbial populations do not exhibit any biogeographical pattern, that is, that the concept of 'everything is everywhere, but the environment selects'15 may hold for microorganisms. Thus, if all microbes are geographically ubiquitous: why be concerned with any individual environment? They are unlikely to be at risk of extinction. However, this assumption does not hold anymore, as the existence of microbial endemism is now widely recognised. ${ }^{16}$ Indeed, many pathogens and plant-associated microbes have (or had until humans transported them) well-defined biogeographical distributions. 


\section{Protecting genetic resources}

The issue of endemism is of great academic and practical interest and has now become a critical issue in the global focus on microbial (and other) genetic catalogues as an economically valuable resource. Following the adoption in 1992 of a global convention relating to the sovereignty of genetic resources (The Convention on Biological Diversity: www.cbd.int), a number of countries have established national legislation relating to the protection of their 'endemic' genetic resources. South Africa is one of these countries; in 2004, the government promulgated the South African National Environmental Management: Biodiversity Act 10, establishing a set of guidelines for the protection, management, use and exploitation of South African genetic resources, along with a legal requirement for income relating to the use of such resources to be shared equitably with the 'owners' of that resource (South Africa's Bioprospecting, Access and Benefit-Sharing Regulatory Framework; www.environment.gov.za).

The legislation was also designed to protect the country against biopiracy; the loss of the intellectual property relating to the development of widely commercialised appetite-suppressive preparations from the nearindigenous Hoodia gordonii undoubtedly influenced the development of this legislation. ${ }^{17}$

While the new bioprotection legislation is entirely within the spirit of the Convention on Biological Diversity, its practical implementation has raised certain anomalies and complications - exemplifying 'the law of unintended consequences'. For example, a microbiologist wishing to publish the characterisation of a new bacterial or fungal isolate is required by all international journals to first deposit a culture in one or more international repositories. However, doing so in this country would be a breach of the legislation if an export permit has not been obtained, and is theoretically subject to a substantial fine and/or jail sentence whether or not the new isolate is in fact ubiquitous in a global sense.

Irrespective of the framing of South Africa's biosecurity legislation, the issue of the nation's genetic resources remains a critical element of future conservation and commercial exploitation considerations. This is particularly important for endangered soil habitats (e.g. those threatened by agriculture and urban development) and soil types, where the most diverse microbial communities exist. ${ }^{18}$

\section{Why understanding microorganisms is important}

We live in a world dominated by microbes. However, microbes are important not only because of their astonishing numbers, but because of the services they provide to ecosystems/society. Here are three very different examples:

(1) In hydrothermal vent communities (Figure 1) and other reducing habitats, chemoautotrophic symbionts provide organic nutrients for animal hosts in at least seven different phyla. The activities of these individual symbioses contribute to nested communities that include nonsymbiotic animal and microbial species that are able to exist through the symbiotic primary production that is not driven by solar energy but rather by sulphide, hydrogen, methane, and other reduced energy sources..$^{19,20}$

(2) At both ends of the biotic temperature scale, primary production and nitrogen fixation, carried out by bacterial communities that thrive beneath quartz and translucent rocks (Figure 2) are thought to be important food sources for grazing nematodes and protozoans, and therefore the basis for the survival of whole ecosystems. ${ }^{21}$

(3) Bacterial communities in floral nectar can influence the way animals such as pollinators interact with plants. The common bacterium Gluconobacter sp. changes the chemical properties of the nectar, reducing nectar consumption by pollinators, and weakening the plantpollinator mutualism. ${ }^{22}$

Many of the global-change drivers that affect plant and animal populations, such as rising $\mathrm{CO}_{2}$ concentrations, global warming, and altered precipitation regimes, simultaneously influence the abundance and composition of microbial communities. ${ }^{23}$ Equally, global climate chang ${ }^{24}$ and the movement of plants ${ }^{25}$ and animals ${ }^{26}$, including humans, could act synergistically to promote microbial invasions; which, in turn, could pose a challenge to endemic microbial communities.

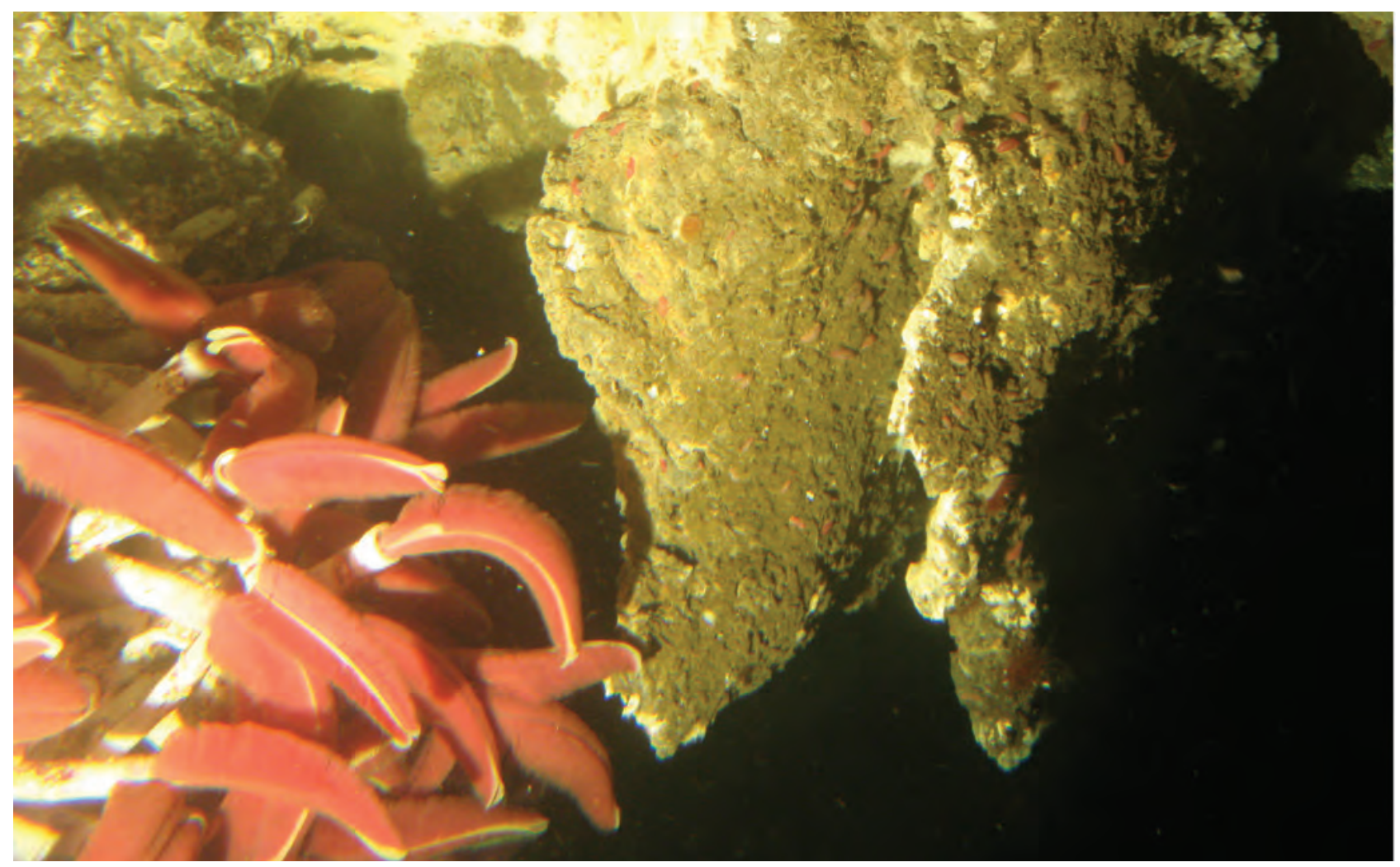

Photo: Don Cowan

Figure 1: Riftia tubeworms on a hydrothermal vent chimney (2010 m deep at East Pacific Rise $\left.9^{\circ} 50^{\prime} \mathrm{N}\right)$, which contains populations of symbiotic chemoautotrophic microorganisms. 

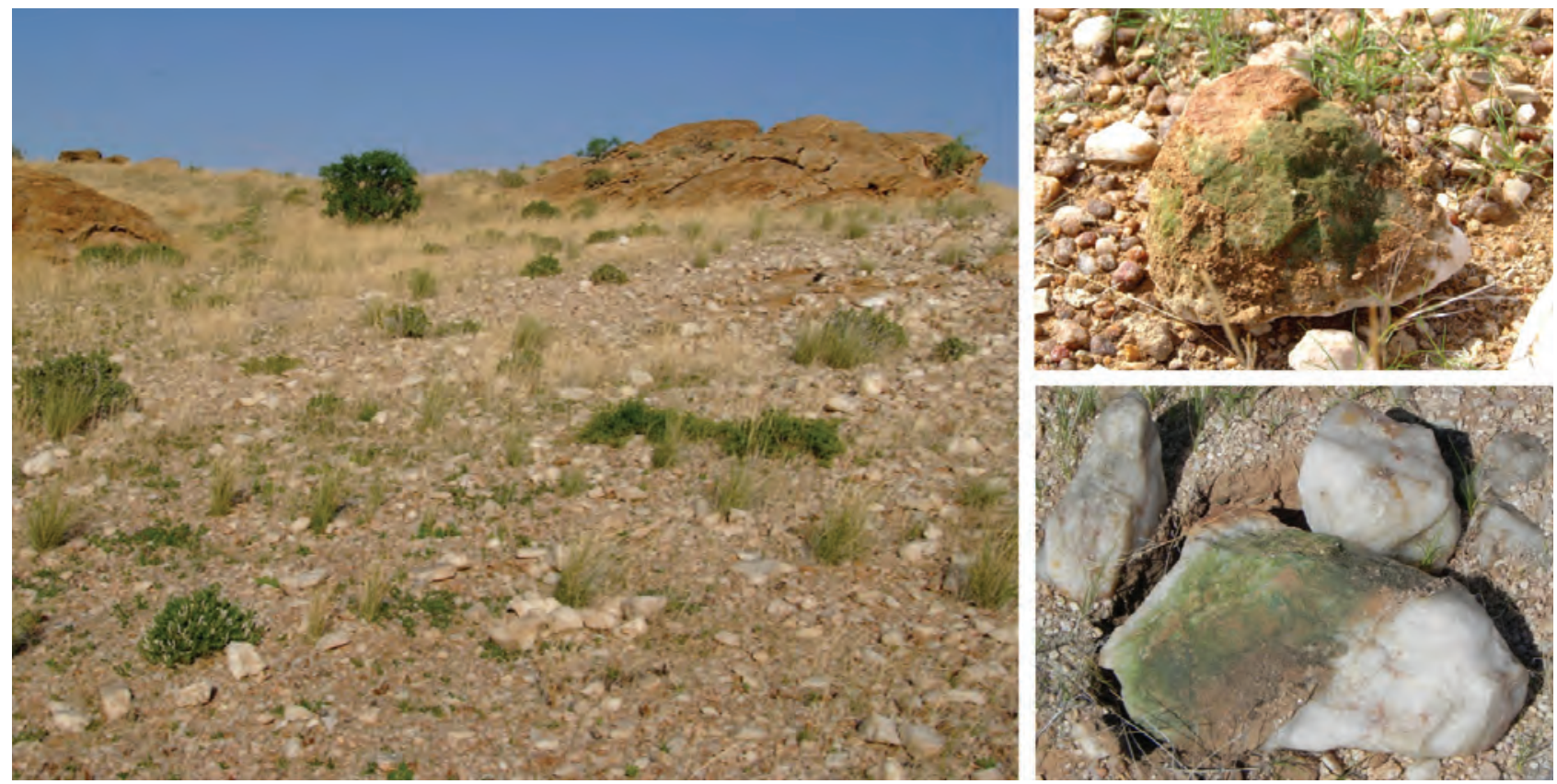

Photos: Don Cowan and Ed Rybicki

Figure 2: South Africa's cryptic biodiversity. Deserts, which cover a substantial proportion of South Africa's land area, are extreme environments where microorganisms inhabit specialised, often cryptic (hidden) niches. Hypolithic communities, found on the undersides of translucent rocks, represent 'hotspots' of microbial biodiversity.

There are some excellent and well-documented examples of microbial endemism. ${ }^{16}$ Cho and Tiedje27 isolated fluorescent pseudomonads from 38 undisturbed pristine soil samples from 10 sites on four continents and revealed no overlap in genotypes between sites or between continents. Geographical isolation has also been demonstrated for archaea thriving in hot springs ${ }^{28}$, and bacteria found in seawate ${ }^{29}$ and sediments ${ }^{30}$. Furthermore, recent global surveys indicate that most bacteria are restricted to broad habitat types, and there is little overlap among bacterial taxa found in soils, sediments, fresh water and seawater. ${ }^{31,32}$ Hence, despite the 'everything is everywhere' hypothesis, dispersal limitation and differences in environmental factors deeply affect the establishment of endemic microbes. It is, therefore, a valid assumption that South Africa, given its enormous geographical and habitat variation, harbours a high level of microbial endemism.

\section{South Africa's (microbial) genetic resources}

\section{Marine ecosystems}

Microorganisms constitute more than $90 \%$ of the living biomass in the sea, are responsible for $98 \%$ of primary production and are a major force behind the nutrient and energy cycles in the world's oceans. ${ }^{33}$ The various oceanic zones present profoundly different physical, chemical and biological properties. ${ }^{34}$ Therefore, understanding the patterns of microbial distribution is crucial in order to anticipate the responses of marine ecosystems to environmental changes. ${ }^{34}$ Global ocean studies have identified remarkable large-scale patterns across different ecosystems, ${ }^{33-35}$ and the general consensus is that the ocean is an 'underexplored and rare biosphere' ${ }^{35}$ with respect to the microbial diversity contained within it. The inescapable inference is that microbes account for the majority of the genetic and metabolic variation in the oceans, which remains under-sampled and essentially uncharted. For example, viruses are seldom taken into account in estimating rates of carbon cycling in the world's oceans - yet they are the most abundant marine organisms; it is estimated that they cause the death of $50 \%$ of oceanic bacteria every day, and they undoubtedly significantly influence the availability of soluble organic carbon in ways that are only beginning to be understood. ${ }^{36}$
It is no surprise that despite an approximately $3000-\mathrm{km}$ long southern African coastline, almost nothing is known regarding the microbial biodiversity in this biome (Figure 3). Previous efforts in assessing marine biodiversity have focused only on the identification and study of the flora and fauna, a significant proportion of which are endemic. ${ }^{37}$ Yet it is a little recognised fact that even greater microbial endemism is associated with these macroorganisms. Southern African marine invertebrates (particularly sponges, tunicates and tube worms) have attracted much attention because of their production of potent compounds with biomedical potential. ${ }^{38}$ Interestingly, it is becoming apparent that these compounds do not actually originate from the invertebrates, but are rather produced as secondary metabolites by the symbiotic microorganisms that inhabit them. However, very little is known about the diversity of sponge-associated microbes and the viruses that may regulate these communities. Only one study has reported on the bacterial community associated with a South African sponge: Tsitsikamma favus, from which a unique pyrroloiminoquinone was isolated. ${ }^{39}$

A variety of South African derived marine sediments and samples have been recently screened for bacteria able to produce a range of activities or products for biotechnological application. These organisms include, for example, those displaying hydrocarbon utilisation ${ }^{40}$ and bioflocculant production ${ }^{41-43}$. Culturable fungi from marine sediments were characterised in St. Helena Bay ${ }^{44}$ : extracellular cellulases were produced by filamentous fungal isolates, indicating their probable role in detrital decay processes and therefore in the carbon cycle on the ocean bed. But, to the best of our knowledge, only one study has focused on microbial distribution patterns in South African open water, with the aim of understanding their role in ecosystem functioning. ${ }^{45}$ The Micro B3 Ocean Sampling Day initiative (http://www.microb3.eu/), a sampling campaign of the world's oceans in the year 2014, could, however, be an important starting point for a better understanding of the diversity and function harboured in our oceans.

\section{Non-pathogenic plant-associated microbes}

Plant-associated microbes may provide the plant with physiologically accessible nutrients and phytohormones that improve plant growth, may suppress phytopathogens or may help plants to cope with stressors such as heat, drought and salt. ${ }^{46}$ Symbiotic associations between rhizobia, a group of nitrogen-fixing bacteria, and legumes are one of the best 


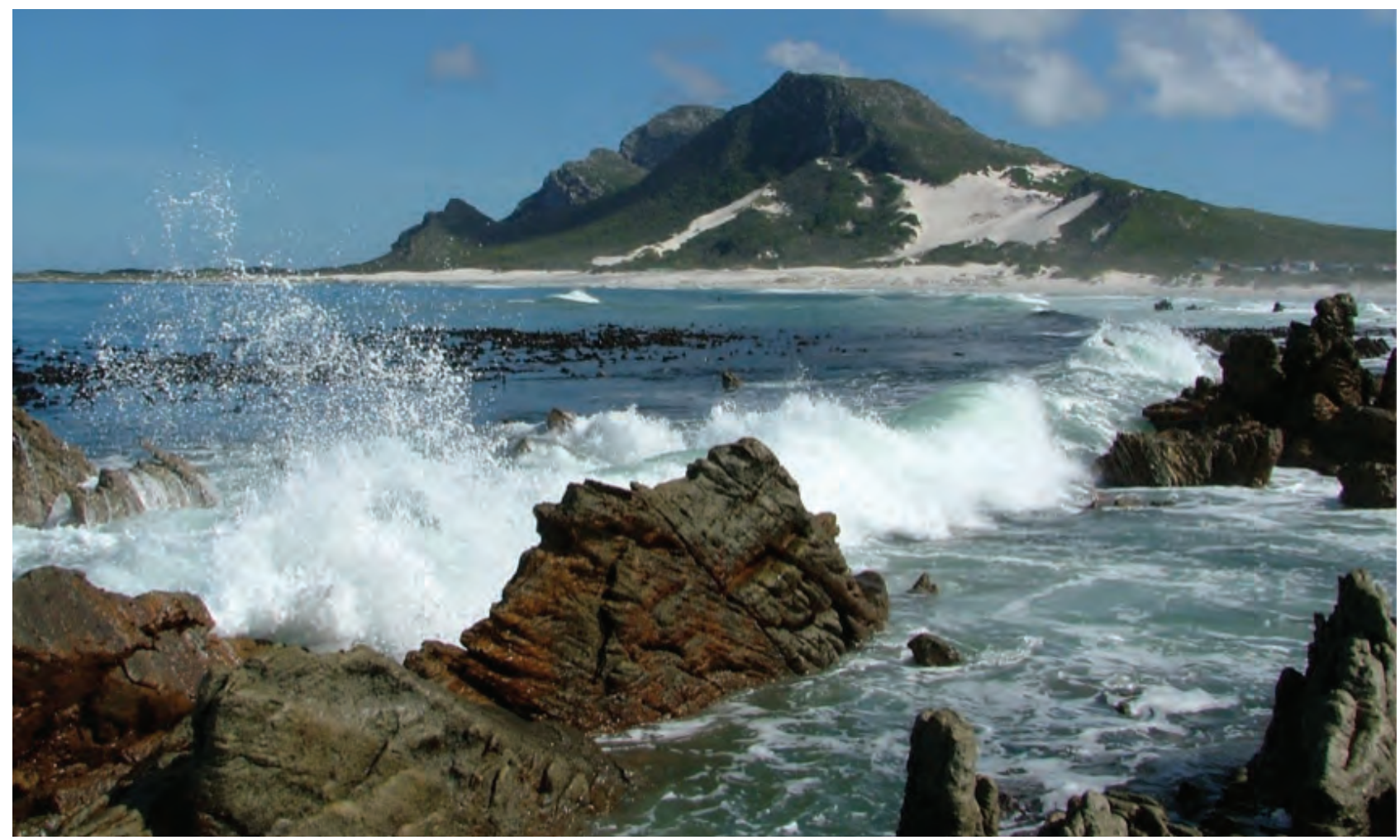

Photos: Don Cowan

Figure 3: South Africa's marine coastal zones, especially those impacted by the western Benguela Upwelling System, are particularly rich in biomass and biodiversity. Much of the eukaryotic (and most of the prokaryotic) diversity is completely unexplored.

examples of these plant-microbe interactions.$^{47}$ Nitrogen-fixing bacteria are important regulators of plant productivity because plants cannot fix atmospheric nitrogen and because nitrogen is, together with phosphorus and potassium, the main element that limits plant productivity. ${ }^{48}$ To date very little is known about the types of rhizobia nodulating South African legumes. Although the majority of legumes form symbioses with members of the genus Rhizobium and its relatives (alphaproteobacteria), some legumes, such as those of the genus Aspalathus, are nodulated by beta-proteobacteria of the genus Burkholderia. ${ }^{49-51}$ Although beta-rhizobia are particularly associated with mimosas and acacias, they also nodulate several agriculturally important legumes, including honeybush tea (Cyclopia spp.), thus raising the possibility that they could be used as biofertilisers. Their particular characteristics (e.g. tolerance to $\mathrm{pH}$ extremes and high salt concentrations) make them suited to specific environments, such as those in the Cape region ${ }^{49}$ (Figure 4). The negative aspect of this mutually beneficial relationship is that it can also impact plant diversity and community composition ${ }^{52}$ by enhancing a species' invasive capacity.53,54 Many thousand hectares of unique fynbos vegetation has been colonised by imported Acacia sp. ${ }^{55}$ While the success of acacia in colonising these habitats was thought to be connected with their ability to associate with indigenous nitrogen-fixing bacteria ${ }^{55}$ recent studies have shown that invasive acacias in South African ecosystems tend to nodulate with bacteria that do not overlap with native legumes, and sometimes even with bacteria co-introduced from Australia. ${ }^{56}$

Another important group of plant symbionts that enhance plant productivity by supplying limiting nutrients are mycorrhizal fungi (Figure 5). Mycorrhizal fungi are widespread in nature, where they form symbiotic associations with the roots of $70-80 \%$ of all terrestrial plant species. ${ }^{57}$ Mycorrhizal fungi can provide resistance to disease and drought, and supply nutrients to the plant in exchange for carbon. The most abundant and important groups of mycorrhiza are the arbuscular mycorrhiza, the ectomycorrhiza and the ericoid mycorrhiza. A number of studies have reported mycorrhizal fungi in South Africa. ${ }^{58,59}$ However, very little is known about the community composition, although the high beta diversity of aboveground plant species is expected to influence fungal diversity. Notably, mycorrhizal fungi associate extensively with the Ericacea and Orchidaceae families in South Africa, but not with the Proteaceae, ${ }^{59}$ implying that other microorganisms may fill this niche. In the Cape Floristic Region co-occurring orchid species seem to use different fungal partners, consistent with the expected role of these fungi in reducing competition for nutrients. ${ }^{60}$
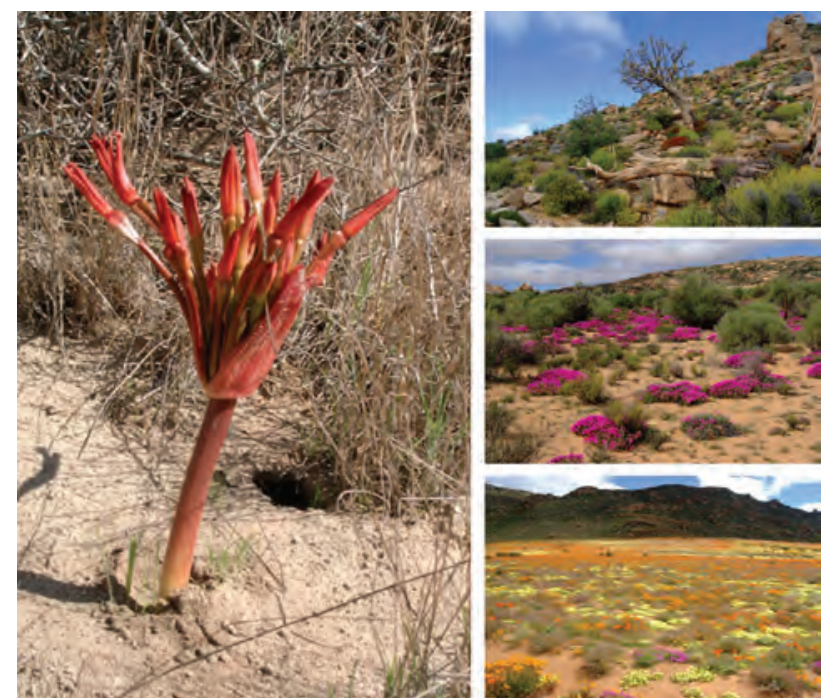

Photos: Don Cowan

Figure 4: South Africa harbours a wealth of floristic diversity. The Cape Floristic Biome alone has over 6000 endemic plant species. There is growing evidence that many of these species may harbour unique rhizospheric and endophytic microorganisms. 

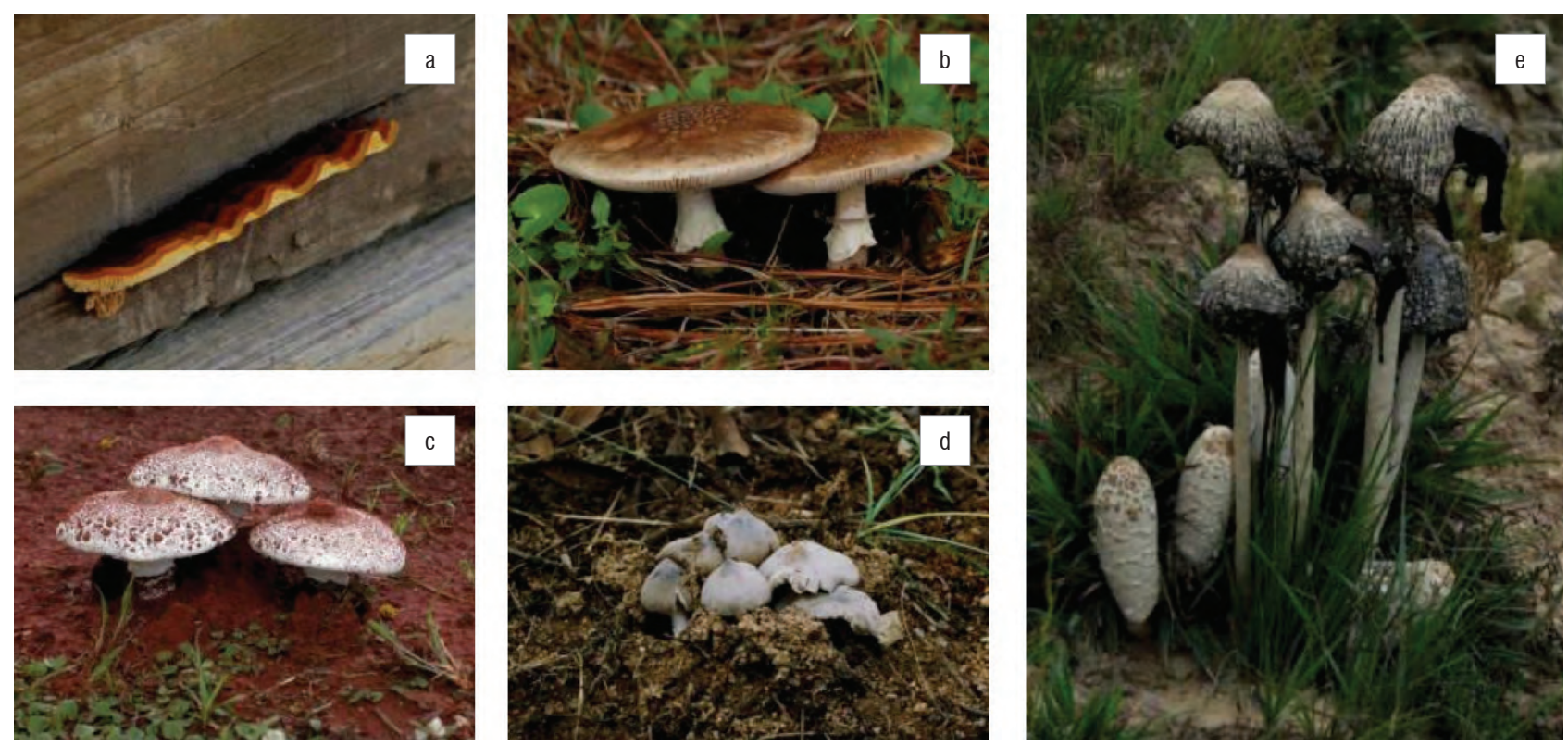

Photos: Wilhelm de Beer, University of Pretoria (reproduced with permission).

Figure 5: South African fungal diversity is vast and largely unexplored. Mostly invisible, except when the fruiting bodies appear, fungi play critical roles in environmental processes such as lignocellulosic degradation by, for example (a) Gleophyllum spp.; as mycorrhizal symbionts of trees, including (b) Amanita spp.; (c,d) as Termitomyces symbionts of termites; and as saprophytes, for example (e) Coprinus spp., that break down dead plant tissues; and in many other processes including as causal agents in plant and animal diseases.

Non-mycorrhizal fungi also associate with plants (Figure 5). An intensive study by Marincowitz et al. ${ }^{61}$ on the saprophytic fungi of plants from the Cape Floristic Region has revealed a large number of undescribed species. Likewise, ophiostomatoid fungi were found to be highly diverse in the infructescences of Protea species. ${ }^{62}$ Next-generation sequencing applied to the study of fungal endophytes in a single Eucalyptus tree has shown that there are about ten times more species present than those that can be isolated. ${ }^{63}$ This finding is not surprising and is similar to those of sampling of many other environments.

The bacteria colonising the rhizosphere (the area immediately surrounding the root) and the endophytic compartment (within the root) of South African plants are even less well understood. Local studies have demonstrated that microbial rhizospheric community structures differ between plant species. For example, Stafford et al. ${ }^{64}$ investigated two endemic species of the Proteaceae family (Leucospermum truncatulum and Leucadendron xanthoconus) and showed that the rhizospheric soil communities were different between plant species but more similar to each other than to non-rhizospheric soil. A study analysing the rhizospheric and endophytic microbial communities associated with South African sorghum reported that specific bacterial taxa are consistently detected in sorghum-created rhizospheric and endophytic environments, irrespective of any biogeographical factors. ${ }^{65}$ The implication of these findings is that these organisms have significant potential in agricultural biotechnology as sorghum (and possibly other crops) improvement tools.

Plant virus diversity in South Africa has never been systematically investigated, although many have been found and characterised, and much damage is known to be done to crop plants in the country ${ }^{66} \mathrm{It}$ is even possible that undiscovered plant viruses may be subtly influencing the distribution and success of native plant species in South Africa: recent findings in virus ecology elsewhere suggest that many viruses in natural ecosystems do no harm at all despite causing persistent infections, and may in fact be mutualistic in terms of providing clear benefit to their hosts ${ }^{67}$ However, no such investigations have ever been done in South Africa, despite the richness and uniqueness of its plant life.

\section{Hypersaline habitats}

Hypersaline environments are those with salt concentrations above that of seawater (3.3\% total dissolved salts), and are widespread in both coastal and inland regions of South Africa (Figure 6). Microbial communities able to withstand these extreme saline conditions have the capacity to regulate the osmotic pressure to resist the denaturing effects of salt in the environment. In addition, a common phenomenon in these environments is the occurrence of gradients in salinity as a result of evaporation, and halophiles are able to rapidly adjust their osmotic equilibrium as required when the outside salinity is changed. These gradients also result in the establishment of very diverse microbial compositions, in which halophilic and halotolerant microorganisms from all four domains of life (eukarya, bacteria, archaea and viruses) can be found. The eukarya are a minority in high salt environments, mostly represented by the halotolerant green algae Dunaliella and only a few fungal species. ${ }^{68}$ Salt-adapted bacteria are spread over a large number of phylogenetic groups ${ }^{69}$ and the majority are moderate rather than extreme halophiles. The extreme hypersaline habitats are dominated by the archaea, and often display a bright red colour as a result of the large number of pigmented haloarchaea. ${ }^{70}$ Nevertheless, very little is known about the diversity of viruses in these environments (Figure 7), although projects are underway in South Africa to start filling this gap (MI Tuffin, EP Rybicki, M Pfaff, unpublished results).

The dense microbial communities occurring in these environments often exhibit high activities of photosynthesis, dissimilatory sulphate reduction and other microbial processes, thereby exerting a profound influence on biogeochemical cycles. ${ }^{71}$ During the highly evaporative stages, the microorganisms become entrapped within the halite crystals enabling them to retain their viability for long periods. ${ }^{72}$ Microbial survival within salt crystals has become a popular topic, relevant to a range of disciplines including geology, biogeography, evolution and even space exploration. ${ }^{68,73}$ In addition, halophilic and halotolerant microorganisms have found interesting biotechnological applications as a result of the large variety of stable and unique biomolecules they are able to produce.

Salt lakes (also referred to as salt pans or vleis) are numerous and geographically widespread in South Africa, but the majority are inland, shallow and contain water only ephemerally. ${ }^{74}$ Vleis in the southwestern Cape Province are usually temporary or permanent 


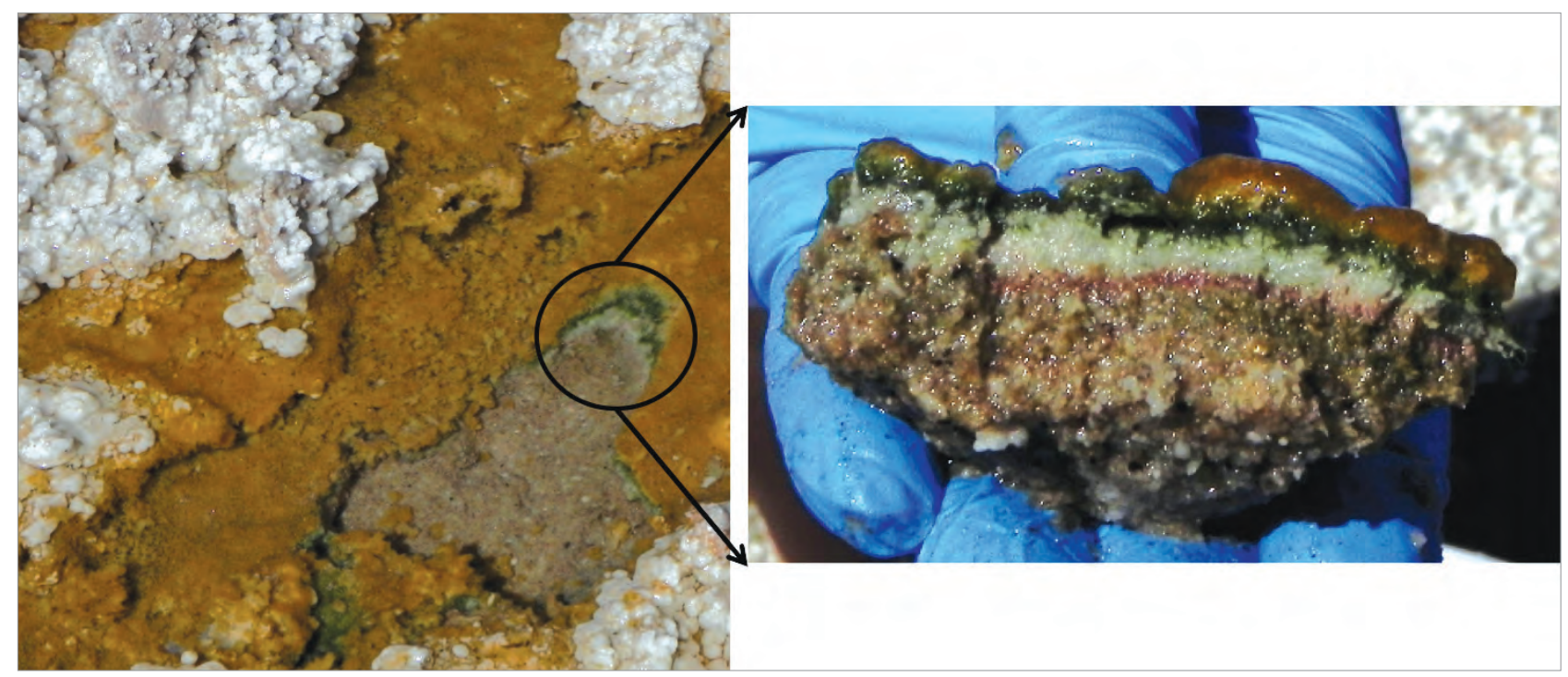

Photos: Ed Rybicki

Figure 6: A microbial mat from a hypersaline stream, showing stratified biomass of microorganisms embedded in extracellular polymeric and mineralised materials. Light penetrates only a few millimetres into the mats and oxygen produced by photosynthesis rapidly diminishes with depth. Turnover of carbon fixed in the upper portion of the mats is affected by fermentation processes and sulphate reduction deeper in the mat.
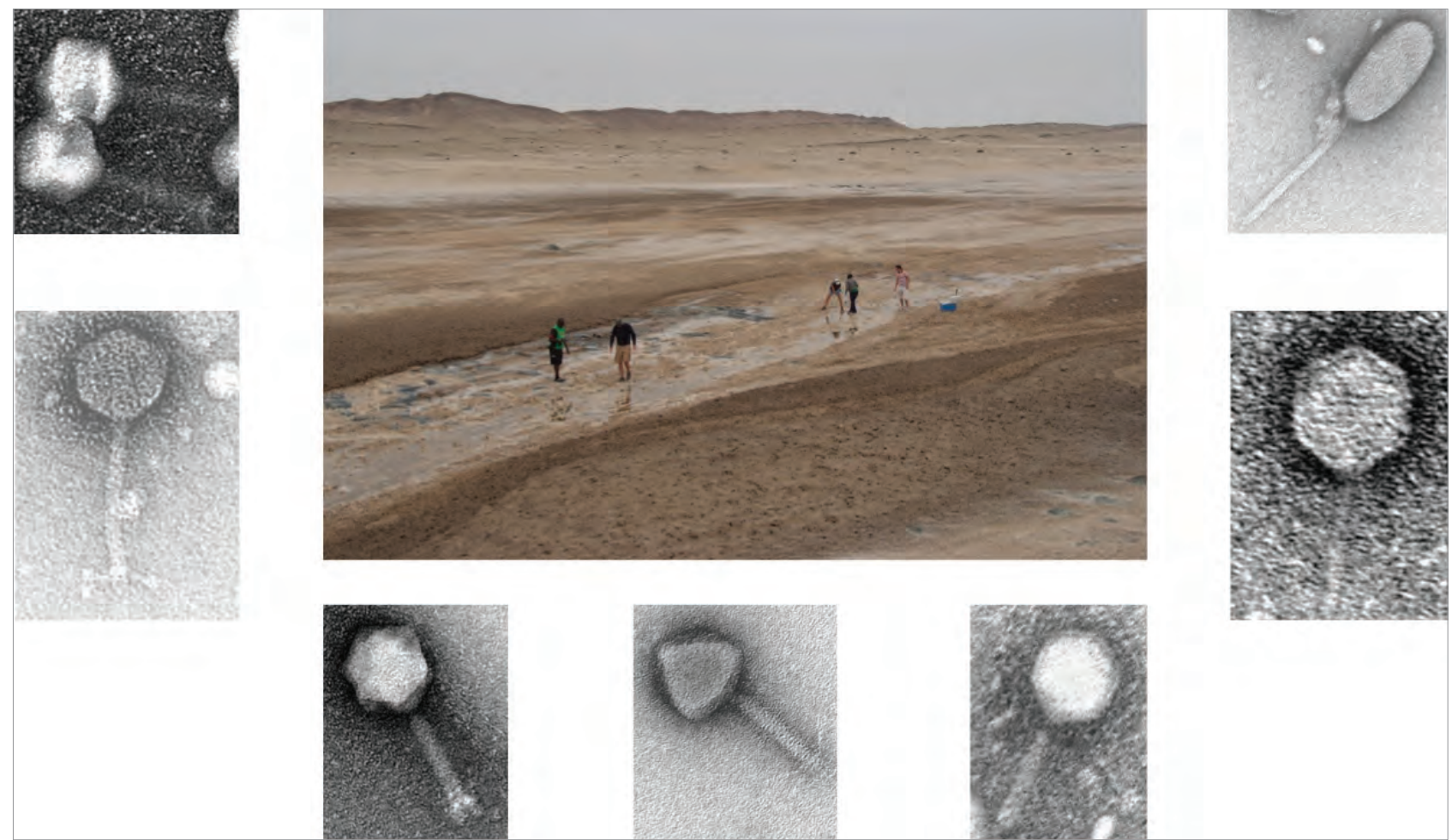

Photo: Don Cowan; micrographs: Lonnie van Zyl, University of the Western Cape (reproduced with permission).

Figure 7: South Africa's extensive desert areas, and their associated saline springs, harbour a wide variety of bacteriophages, about which almost nothing is known. Soil and saline water filtrates show large numbers of myoviruses and siphoviruses.

lakelets and/or marshes, or even estuarine lagoons. The best studied are the hypersaline pans in the Darling and Yzerfontein regions, which include coastal and inland brackish to saline and brine pans. ${ }^{75}$ To our knowledge, only four reports have been published on the microbial diversity associated with South African salt pans..$^{76-79}$ One of these studies ${ }^{77}$ reported nanoarchaea, previously found in hyperthermophilic and mesophilic halophilic environments, demonstrating that this group of very unusual and rare microorganisms may be much more widely distributed and more physiologically flexible than previously thought. Sulphate-reducing bacterial community structures have also been investigated..$^{79,80}$ Spatial and temporal analyses demonstrated that similar microbial populations were generally found in individual pans but varied from one pan to another. Phylogenetic analyses showed that most of the sulphate reducers were members of the Desulfobacteraceae 
and Desulfohalobiaceae families. Sulphate reducers are important for sulphur and carbon cycling, accounting for more than $50 \%$ of the organic carbon mineralisation in marine sediments. Therefore, an understanding of sulphate-reducing microbial communities is important to predict changes in ecosystem functioning.

\section{Factors negatively affecting discovery of microbial diversity}

Until recently, microbial diversity and ecology were certainly not priority research areas, in comparison with plant ecology, for example. However, we note with some gratification that the South African National Biodiversity Institute (www.sanbi.org.za) has now identified microbial diversity as a priority area for research.

The problem has been exacerbated by the relatively small size of the academic community involved in environmental microbiology research, compared with that dedicated to the study of (macro) flora and fauna - possibly because of the more charismatic nature of the latter. The relatively high cost of modern molecular technologies (deep sequencing of phylogenetic markers, metatranscriptomics, metaproteomics etc.) has also contributed to the slow growth of the microbial ecology research community.

We argue that it should not be this way: given our limited understanding of the immense contribution of microbes to everything from human digestion to soil and oceanic carbon cycling, our research priorities should surely swing to more properly understanding these contributions, how they affect the diversity of plants and animals, and, more selfishly, how they affect our species.

\section{Opportunities: New technologies}

The opportunities afforded to budding microbial ecologists by South Africa's amazing microbial diversity are literally boundless. Not only do our many terrestrial and marine microenvironments offer the promise of an almost unimaginable microbial diversity, but we now have ready access to the advanced technology needed to catalogue it. Next-generation and even third-generation nucleic acid sequencing techniques are available in the country, or via courier service to Asia, Europe or even the USA. The computer requirements for analysis are largely met within South Africa; the software is increasingly available, and often free. As with many other fields of research, the high profile and strong funding base of the biomedical community will drive much of the transition from culture-based and immunological identification of microbes to metagenomic identification - and will make it easier for everyone else to join in.

The rewards will be immediate, in the sense of information on medical risks, and short term, with regard to information on environmental hazards and unsuspected role-players in carbon trafficking and other energy flows, to long term in the sense of understanding how global oceanic and soil carbon flows actually work. We will, for the first time, understand how all the players in an ecosphere actually interrelate - from the nanoscale (viruses) to the macroscale (plants and animals).

It is time that we engaged across the entire spectrum of biodiversity and time to consider how everything meshes together to govern all the processes that we consider important. And it is time to acknowledge the presence of and to study organisms beyond those that generate tourist revenue.

\section{Acknowledgements}

We gratefully acknowledge the numerous funding bodies that have supported our research activities, and particularly thank the National Research Foundation of South Africa.

\section{References}

1. Corliss JB, Dymond J, Gordon LI, Edmond JM, Herzen RPV, Ballard RD, et al. Submarine thermal springs on the Galapagos rift. Science. 1979;203:10731083. http://dx.doi.org/10.1126/science.203.4385.1073

2. Whitman WB, Coleman DC, Wiebe WJ. Prokaryotes: The unseen majority. Proc Natl Acad Sci USA. 1998;95(12):6578-6583. http://dx.doi.org/10.1073/ pnas.95.12.6578
3. Li K, Bihan M, Yooseph S, Methe BA. Analyses of the microbial diversity across the human microbiome. Plos One. 2012;7(6):e32118. http://dx.doi. org/10.1371/journal.pone.0032118

4. Fry JC, Parkes RJ, Cragg BA, Weightman AJ, Webster G. Prokaryotic biodiversity and activity in the deep subseafloor biosphere. FEMS Microbiol Ecol. 2008;66(2):181-196. http://dx.doi.org/10.1111/j.15746941.2008.00566.x

5. Angly FE, Felts B, Breitbart M, Salamon P, Edwards RA, Carlson C, et al. The marine viromes of four oceanic regions. Plos Biol. 2006;4(11):2121-2131. http://dx.doi.org/10.1371/journal.pbio.0040368

6. Curtis TP, Sloan WT, Scannell JW. Estimating prokaryotic diversity and its limits. Proc Natl Acad Sci USA. 2002;99(16):10494-10499. http://dx.doi. org/10.1073/pnas.142680199

7. Hawksworth DL. The magnitude of fungal diversity: The 1.5 million species estimate revisited. Mycol Res. 2001;105:1422-1432. http://dx.doi. org/10.1017/S0953756201004725

8. Ley RE, Peterson DA, Gordon Jl. Ecological and evolutionary forces shaping microbial diversity in the human intestine. Cell. 2006;124(4):837-848. http:// dx.doi.org/10.1016/j.cell.2006.02.017

9. Woese CR, Fox GE. Phylogenetic structure of prokaryotic domain - primary kingdoms. Proc Natl Acad Sci USA. 1977;74(11):5088-5090. http://dx.doi. org/10.1073/pnas.74.11.5088

10. Amann RI, Ludwig W, Schleifer K-H. Phylogenetic identification and in situ detection of individual microbial cells without cultivation. Microbiol Rev. 1995;59(1):143-169.

11. Griffith GW. Do we need a global strategy for microbial conservation? Trends Ecol Evol. 2012;27(1):1-2. http://dx.doi.org/10.1016/j.tree.2011.10.002

12. Røy H, Kallmeyer J, Adhikari RR, Pockalny R, Jorgensen BB, D'Hondt S. Aerobic microbial respiration in 86-million-year-old deep-sea red clay. Science. 2012;336(6083):922-925. http://dx.doi.org/10.1126/science.1219424

13. McGillicuddy DJ Jr., Anderson LA, Bates NR, Bibby T, Buesseler KO, Carlson $\mathrm{CA}$, et al. Eddy/wind interactions stimulate extraordinary mid-ocean plankton blooms. Science. 2007;316(5827):1021-1026. http://dx.doi.org/10.1126/ science. 1136256

14. Kellogg CA, Griffin DW. Aerobiology and the global transport of desert dust. Trends Ecol Evol. 2006;21(11):638-644. http://dx.doi.org/10.1016/j. tree.2006.07.004

15. Baas-Becking LGM. Geobiologie of Inleiding Tot de Milieukunde (Van Stockkum and Zoon) [Geobiology or introduction to the science of the environment]. The Hague: W.P. Van Stockum \& Zoon; 1934. Dutch.

16. Hanson CA, Fuhrman JA, Horner-Devine MC, Martiny JBH. Beyond biogeographic patterns: Processes shaping the microbial landscape. Nat Rev Microbiol. 2012;10:497-506.

17. Joffe F. The hoo-ha about Hoodia in South Africa. IAM Magazine [serial on the Internet]. 2008 Feb 04 [cited 2013 Nov 06]:19-21. Available from: http:// www.iam-magazine.com/issues/article.ashx?g $=5$ a9f375c-e3dc-47de8503-dd4e2eecd1ad

18. Parker SS. Buried treasure: Soil biodiversity and conservation. Biodivers Conserv. 2010;19:3743-3756. http://dx.doi.org/10.1007/s10531-010-9924-8

19. Dubilier N, Bergin C, Lott C. Symbiotic diversity in marine animals: The art of harnessing chemosynthesis. Nat Rev Microbiol. 2008;6(10):725-740.

20. Petersen JM, Zielinski FU, Pape T, Seifert R, Moraru C, Amann R, et al. Hydrogen is an energy source for hydrothermal vent symbioses. Nature. 2011;476(7359):176-180. http://dx.doi.org/10.1038/nature10325

21. Cary SC, McDonald IR, Barrett JE, Cowan DA. On the rocks: The microbiology of Antarctic dry valley soils. Nat Rev Microbiol. 2010;8(2):129-138. http:// dx.doi.org/10.1038/nrmicro2281

22. Vannette RL, Gauthier MPL, Fukami T. Nectar bacteria, but not yeast, weaken a plant-pollinator mutualism. Proc R Soc B. 2013;280(1752), Art.\# 20122601. http://dx.doi.org/10.1098/rspb.2012.2601

23. Blankinship JC, Niklaus PA, Hungate BA. A meta-analysis of responses of soil biota to global change. Oecologia. 2011;165:553-565. http://dx.doi. org/10.1007/s00442-011-1909-0 
24. Walther G-R, Roques A, Hulme PE, Sykes MT, Pysek P, Kuehn I, et al. Alien species in a warmer world: Risks and opportunities. Trends Ecol Evol. 2009;24(12):686-693. http://dx.doi.org/10.1016/j.tree.2009.06.008

25. Rout ME, Callaway RM. Interactions between exotic invasive plants and soil microbes in the rhizosphere suggest that 'everything is not everywhere'. Ann Bot-London. 2012;110(2):213-222. http://dx.doi.org/10.1093/aob/mcs061

26. Litchman E. Invisible invaders: Non-pathogenic invasive microbes in aquatic and terrestrial ecosystems. Ecol Lett. 2010;13(12):1560-1572. http://dx.doi. org/10.1111/j.1461-0248.2010.01544.x

27. Cho JC, Tiedje JM. Biogeography and degree of endemicity of fluorescent Pseudomonas strains in soil. Appl Environ Microbiol. 2000;66(12):54485456. http://dx.doi.org/10.1128/AEM.66.12.5448-5456.2000

28. Whitaker RJ, Grogan DW, Taylor JW. Geographic barriers isolate endemic populations of hyperthermophilic archaea. Science. 2003;301(5635):976978. http://dx.doi.org/10.1126/science.1086909

29. Sul WJ, Oliver TA, Ducklow HW, Amaral-Zettler LA, Sogin ML. Marine bacteria exhibit a bipolar distribution. Proc Natl Acad Sci USA. 2013;110(6):23422347. http://dx.doi.org/10.1073/pnas.1212424110

30. Horner-Devine MC, Lage M, Hughes JB, Bohannan BJM. A taxa-area relationship for bacteria. Nature. 2004;432(7018):750-753. http://dx.doi. org/10.1038/nature03073

31. Lozupone CA, Knight R. Global patterns in bacterial diversity. Proc Natl Acad Sci USA. 2007;104(27):11436-11440. http://dx.doi.org/10.1073/ pnas.0611525104

32. Nemergut DR, Costello EK, Hamady M, Lozupone C, Jiang L, Schmidt SK, et al. Global patterns in the biogeography of bacterial taxa. Environ Microbiol. 2011;13(1):135-144. http://dx.doi.org/10.1111/j.1462-2920.2010.02315.x

33. Suttle CA. Marine viruses - Major players in the global ecosystem. Nat Rev Microbiol. 2007;5(10):801-812. http://dx.doi.org/10.1038/nrmicro1750

34. Zinger L, Amaral-Zettler LA, Fuhrman JA, Horner-Devine MC, Huse SM, Welch DBM, et al. Global patterns of bacterial beta-diversity in seafloor and seawater ecosystems. Plos One. 2011;6(9):e24570. http://dx.doi.org/10.1371/journal. pone. 0024570

35. Sogin ML, Morrison HG, Huber JA, Mark Welch D, Huse SM, Neal PR, et al. Microbial diversity in the deep sea and the underexplored 'rare biosphere'. Proc Natl Acad Sci USA. 2006;103(32):12115-12120. http://dx.doi. org/10.1073/pnas.0605127103

36. Weitz JS, Wihelm SW. Ocean viruses and their dynamical effects on microbial communities and biogeochemical cycles. Biol Rep. 2012;4:17.

37. Branch GM, Griffits CL, Branch ML, Beckley LE. Two Oceans - A guide to marine life in southern Africa. Cape Town: David Philip; 1994.

38. Coleman DM, Sunassee S. Marine bioprospecting in southern Africa. Berlin: Springer-Verlag; 2012.

39. Walmsley TA, Matcher GF, Zhang F, Hill RT, Davies-Coleman MT, Dorrington RA. Diversity of bacterial communities associated with the Indian Ocean sponge Tsitsikamma favus that contains the bioactive pyrroloiminoquinones, tsitsikammamine a and b. Mar Biotechnol. 2012;14(6):681-691. http:// dx.doi.org/10.1007/s10126-012-9430-y

40. Moxley K, Schmidt S. Isolation of a phenol-utilizing marine bacterium from Durban Harbour (South Africa) and its preliminary characterization as Marinobacter sp. KM2. Water Science Technol. 2012;65(5):932-939. http:// dx.doi.org/10.2166/wst.2012.940

41. Cosa S, Mabinya LV, Olaniran AO, Okoh Al. Production and characterization of bioflocculant produced by Halobacillus sp Mvuyo isolated from bottom sediment of Algoa Bay. Environ Technol. 2012 2012;33(9):967-973.

42. Cosa S, Mabinya LV, Olaniran A0, Okoh 00, Bernard K, Deyzel S, et al. Bioflocculant production by Virgibacillus $\mathrm{sp}$. Rob isolated from the bottom sediment of Algoa Bay in the Eastern Cape, South Africa. Molecules. 2011;16(3):2431-2442. http://dx.doi.org/10.3390/molecules16032431

43. Nontembiso P, Sekelwa C, Leonard MV, Anthony OI. Assessment of bioflocculant production by Bacillus $\mathrm{sp}$. Gilbert, a marine bacterium isolated from the bottom sediment of Algoa Bay. Marine Drugs. 2011;9(7):12321242. http://dx.doi.org/10.3390/md9071232
44. Mouton M, Postma F, Wilsenach J, Botha A. Diversity and characterization of culturable fungi from marine sediment collected from St. Helena Bay, South Africa. Microb Ecol. 2012;64(2):311-319. http://dx.doi.org/10.1007/ s00248-012-0035-9

45. Pommier T, Canback B, Riemann L, Bostrom KH, Simu K, Lundberg P, et al. Global patterns of diversity and community structure in marine bacterioplankton. Mol Ecol. 2007;16(4):867-880. http://dx.doi.org/10.1111/ j.1365-294X.2006.03189.x

46. Bonfante P, Anca IA. Plants, mycorrhizal fungi, and bacteria: A network of interactions. Annu Rev Microbiol. 2009;63:363-383. http://dx.doi. org/10.1146/annurev.micro.091208.073504

47. Sprent Jl. Nodulation in legumes. Kew: Royal Botanical Gardens; 2001.

48. Chapin FS. The mineral-nutrition of wild plants. Annu Rev Ecol Syst. 1980;11:233-260. http://dx.doi.org/10.1146/annurev.es.11.110180.001313

49. Elliott GN, Chen W-M, Bontemps C, Chou J-H, Young JPW, Sprent Jl, et al. Nodulation of Cyclopia spp. (Leguminosae, Papilionoideae) by Burkholderia tuberum. Ann Bot. 2007;100(7):1403-1411. http://dx.doi.org/10.1093/aob/ $\mathrm{mcm} 227$

50. Moulin L, Munive A, Dreyfus B, Boivin-Masson C. Nodulation of legumes by members of the beta-subclass of Proteobacteria. Nature. 2001;411(6840):948-950. http://dx.doi.org/10.1038/35082070

51. Hassen Al, Bopape FL, Habig J, Lamprecht SC. Nodulation of rooibos (Aspalathus linearis Burm. f.), an indigenous South African legume, by members of both the $\alpha$-proteobacteria and $\beta$-proteobacteria. Biol Fert Soils. 2012;48:295-303. http://dx.doi.org/10.1007/s00374-011-0628-3

52. Van der Heijden MGA, Bakker R, Verwaal J, Scheublin TR, Rutten M, Van Logtestijn R, et al. Symbiotic bacteria as a determinant of plant community structure and plant productivity in dune grassland. FEMS Microbiol Ecol. 2006;56(2):178-187. http://dx.doi.org/10.1111/j.1461-0248.2007.01139.x

53. Van der Heijden MGA, Bardgett RD, Van Straalen NM. The unseen majority: Soil microbes as drivers of plant diversity and productivity in terrestrial ecosystems. Ecol Lett. 2008;11(3):296-310. http://dx.doi.org/10.1111/ j.1461-0248.2007.01139.x

54. Parker MA, Malek W, Parker IM. Growth of an invasive legume is symbiont limited in newly occupied habitats. Divers Distrib. 2006;12(5):563-571. http://dx.doi.org/10.1111/j.1366-9516.2006.00255.x

55. Sprent JI, Parsons R. Nitrogen fixation in legume and non-legume trees. Field Crop Res. 2000;65(2-3):183-196. http://dx.doi.org/10.1016/S03784290(99)00086-6

56. Ndlovu J, Richardson DM, Wilson JRU, Le Roux JJ. Co-invasion of South African ecosystems by an Australian legume and its rhizobial symbionts. J Biogeogr. 2013;40(7):1240-1251. http://dx.doi.org/10.1111/jbi.12091

57. Smith SE, Read DJ. Mycorrhizal symbiosis. London: Academic Press; 2010.

58. Allsopp N, Holmes PM. The impact of alien plant invasion on mycorrhizas in mountain fynbos vegetation. S Afr J Bot. 2001;67(2):150-156.

59. Allsopp N, Stock WD. Mycorrhizal status of plants growing in the Cape Floristic Region, South Africa. Bothalia. 1993;23(1):91-104.

60. Waterman RJ, Bidartondo MI, Stofberg J, Combs JK, Gebauer G, Savolainen $V$, et al. The effects of above- and belowground mutualisms on orchid speciation and coexistence. Am Nat. 2011;177(2):E54-E68. http://dx.doi. org/10.1086/657955

61. Marincowitz S, Groenewald JZ, Wingfield MJ, Crous PW. Species of Botryosphaeriaceae occurring on Proteaceae. Persoonia. 2008;21:111-118. http://dx.doi.org/10.3767/003158508X372387

62. Roets F, Wingfield MJ, Crous PW, Dreyer LL. Fungal radiation in the Cape Floristic Region: An analysis based on Gondwanamyces and Ophiostoma. Mol Phyl Evol. 2009;51(1):111-119. http://dx.doi.org/10.1016/j.ympev.2008. 05.041

63. Kemler M, Garnas J, Wingfield MJ, Pillay KA, Slippers B. Semiconductor DNA sequencing as tool for fungal community analysis: A case study of endophytes in Eucalyptus grandis reveals high diversity. Plos One. In press 2013.

64. Stafford WHL, Baker GC, Brown SA, Burton SG, Cowan DA. Bacterial diversity in the rhizosphere of Proteaceae species. Environ Microbiol. 2005;7(11):17551768. http://dx.doi.org/10.1111/j.1462-2920.2005.00929.x 
65. Ramond JB, Tshabuse F, Bopda CW, Cowan DA, Tuffin MI. Evidence of variability in the structure and recruitment of rhizospheric and endophytic bacterial communities associated with arable sweet sorghum (Sorghum bicolor (L) Moench). Plant Soil. 2013;372(1-2):265-278. http://dx.doi. org/10.1007/s11104-013-1737-6

66. Rybicki EP, Pietersen G. Plant virus disease problems in the developing world. Adv Virus Res. 1999;53:127-175. http://dx.doi.org/10.1016/S00653527(08)60346-2

67. Roossinck MJ. Plant virus ecology. PLoS Pathog. 2013;9(5):e1003304. http://dx.doi.org/10.1371/journal.ppat.1003304

68. Ma Y, Galinski EA, Grant WD, Oren A, Ventosa A. Halophiles 2010: Life in saline environments. Appl Environ Microbiol. 2010;76(21):6971-6981. http://dx.doi.org/10.1128/AEM.01868-10

69. Ventosa A, Nieto JJ, Oren A. Biology of moderately halophilic aerobic bacteria. Microbiol Mol Biol Rev. 1998;62(2):504-544.

70. Oren A. Diversity of halophilic microorganisms: Environments, phylogeny, physiology, and applications. J Ind Microbiol Biot. 2002;28(1):56-63.

71. Foti M, Sorokin DY, Lomans B, Mussman M, Zacharova EE, Pimenov NV, et al. Diversity, activity, and abundance of sulfate-reducing bacteria in saline and hypersaline soda lakes. Appl Environ Microbiol. 2007;73(7):2093-2100. http://dx.doi.org/10.1128/AEM.02622-06

72. Baati H, Guermazi S, Gharsallah N, Sghir A, Ammar E. Microbial community of salt crystals processed from Mediterranean seawater based on 16S rRNA analysis. Can J Microbiol. 2010;56(1):44-51. http://dx.doi.org/10.1139/ W09-102
73. McGenity TJ, Gemmell RT, Grant WD, Stan-Lotter H. Origins of halophilic microorganisms in ancient salt deposits. Environ Microbiol. 2000;2(3):243250. http://dx.doi.org/10.1046/j.1462-2920.2000.00105.x

74. Seaman MT, Ashton PJ, Williams WD. Inland salt waters of South Africa. Hydrobiologia. 1991;210(1-2):75-91. http://dx.doi.org/10.1007/BF00014324

75. Mauger CL, Compton JS. Formation of modern dolomite in hypersaline pans of the Western Cape, South Africa. Sedimentology. 2011;58(7):1678-1692. http://dx.doi.org/10.1111/j.1365-3091.2011.01229.x

76. Prior BA. Properties of two halophilic bacteria from a salt pan. Water SA. 1978;4(3):119-124.

77. Casanueva A, Galada N, Baker GC, Grant WD, Heaphy S, Jones B, et al. Nanoarchaeal 16S rRNA gene sequences are widely dispersed in hyperthermophilic and mesophilic halophilic environments. Extremophiles. 2008;12(5):651-656. http://dx.doi.org/10.1007/s00792-008-0170-x

78. Paper W, Jahn U, Hohn MJ, Kronner M, Naether DJ, Burghardt T, et al. Ignicoccus hospitalis sp nov, the host of 'Nanoarchaeum equitans'. Int J Syst Evol Micr. 2007;57:803-808. http://dx.doi.org/10.1099/ijs.0.64721-0

79. Porter D, Roychoudhury AN, Cowan D. Dissimilatory sulfate reduction in hypersaline coastal pans: Activity across a salinity gradient. Geochim Cosmochim Ac. 2007;71(21):5102-5116. http://dx.doi.org/10.1016/j. gca.2007.08.023

80. Roychoudhury AN, Cowan D, Porter D, Valverde A. Dissimilatory sulphate reduction in hypersaline coastal pans: An integrated microbiological and geochemical study. Geobiology. 2013;11(3):224-233. http://dx.doi. org/10.1111/gbi.12027 